\title{
REIT Performance \\ From Real Estate Mutual Fund Holdings
}

Russell M. Price, Ph.D., Howard University School of Business, USA

\begin{abstract}
The performance of REITs may determine the level of holdings in real estate mutual funds. My study combines the process of asset composition of REITs with the REITs' contribution in real estate mutual fund portfolios. There is a $2 \%$ to $3 \%$ increase in REIT holdings when the dividend yield increases by $1 \%$. The relationship is strongest during the tech bubble period. This will give the investment advisor a look into management of real estate related assets in their respective portfolios.
\end{abstract}

Keywords: REITs; Dividend Yield; Mutual Funds; Asset Holding

\section{INTRODUCTION}

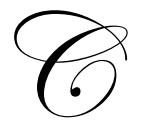

ertain mutual fund styles can be classified by 'specialty' funds, which concentrate their holdings in a particular industry. Of particular interest are real estate mutual funds, whose holdings consist of Real Estate Investment Trusts (REITs) and Real Estate Operating Companies (REOCs). REITs in particular have undergone rapid growth. In 1990, prior to the Omnibus Budget Reconciliation Act of 1993 that changed REIT ownership rules ${ }^{1}$, there were about 117 REITs, with an average market capitalization of about $\$ 800$ million. In 1994, after the Act, there were 130 REITs with an average market capitalization of about $\$ 1.3$ billion. By 2005 , while the number of REITs had declined slightly to 208, the average market capitalization had grown to $\$ 5.2$ billion, representing a compound annual growth rate of more than 20\%. Along with this growth in the REIT market has been an even greater growth in mutual funds that specialize in REITs. Over the same period, the number of real estate mutual funds has grown from 27 to 235, or more conservatively, the number of unique funds (considering only one share class per fund) has grown from 16 to 132. Meanwhile, the total market capitalization of all real estate mutual funds has grown at a compound annual growth rate of nearly $40 \%$, from $\$ 1.4$ billion in 1994 to $\$ 51$ billion in $2005^{2}$. This growth has outpaced the overall growth in sector funds, suggesting that real estate funds may be special among the set of industry-specific investment vehicles ${ }^{3}$. REITs have been known to provide diversification for an investor's portfolio. When REITs are the primary holdings in a mutual fund, the funds offer a multi-layer level of diversification unique in the mutual fund universe.

Fund managers, in their desire to maximize the value and returns of their funds, adjust their holdings periodically. If a security performs well, then the manager would consider increasing his holding in that particular security. In turn, if the security continues to perform well the mutual funds' NAV would increase. A poor performing asset could lead to a decrease in stock holdings. The fund's NAV could decrease due to the underlying value of the poor performing asset. The subsequent changes in the funds' holdings and/or NAV will contribute to fund performance.

\footnotetext{
${ }^{1}$ REITs are authorized pass-through entities for tax purposes if they meet the requirements of the Internal Revenue Code (IRC). One requirement is for the REIT to have at least 100 shareholders with no more of 5 of these holding greater than $50 \%$ of the trust's outstanding shares (the ' $5 / 50$ rule'). The 1993 legislation made it easier for institutions such as pension funds and life insurance companies to invest in REITs, as each account holder counted as a REIT shareholder.

${ }^{2}$ Note that this total underestimates the total ownership of REITs by real estate-specific asset managers. For example, mutual fund managers such as Cohen \& Steers also manage separate accounts where they purchase REITs for clients, such as pension funds and endowments, but these do not enter the mutual fund database.

${ }^{3}$ Tiwari and Vijh (2004) find 308 unique, non-real estate sector funds as of 1999, with a total market value of $\$ 151$ billion, and this was largely driven by 66 technology funds that were worth $\$ 72$ billion at that time.
} 
Studies on the effects of changes of portfolio holdings on mutual fund performance abound. Grinblatt and Titman $(1989,1993)$ use quarterly holdings data of mutual funds from 1975 to 1985 to determine if managers exhibit skill in picking stocks for their respective mutual funds. Jensen's alpha is the performance measure the author's use for the study. They find evidence of a positive alpha from their tests, suggesting that managers could have superior stock picking ability. The effects disappear when transaction costs are included. They also concluded that no benchmark was needed to predict abnormal performance.

Gibson, Safieddine and Titman (2000) look at how mutual fund holdings can be affected by policy changes. The Tax Reform Act of 1986 (TRA 86) legislated a year-end reporting date of October 31 for all mutual funds. The authors investigate the effect of tax-loss selling on holdings. The authors found evidence of reduction in holdings prior to October 31, revealing a November effect.

The level of stock holdings by mutual funds can be affected by the decision of a firm in general to issue dividends or declare a stock split. Grinstein and Michaely (2005) determine that institutions have increased holdings in firms that pay out dividends. Of firms that distribute dividends, institutions preferred low payout firms for their respective portfolios. Higher concentration of holdings did not cause firms to increase their dividend payouts. Rozeff (1998) studies the effects of mutual fund stock split and stock dividend announcements. He finds that similar to common stock splits, high returns occur for a short period prior to the split announcement. The level of holding increases after the fund split. Fernando, Krishnamurthy and Spindt (1999) study quarterly holdings of mutual funds from 1978 to 1993 . The authors conclude that mutual fund splits attract increased fund inflows by investors, but does not significantly alter the level of holdings within the fund.

Badrinath and Wahal (2002) investigate the effects of quarterly holdings by all institutions (banks, insurance companies, pension funds and mutual funds) and whether or not institutions are momentum traders. Their analysis of changes in holdings takes into account stocks that are introduced (denoted entry) and/or removed (denoted exit) from the institution's portfolio. They find that institutional investors act as momentum traders when stocks are brought into the portfolio. Institutions act as contrarian traders when stocks are removed from portfolios or the weights of existing stocks within the portfolio change. In the case of mutual funds, they find a greater sensitivity to changes in portfolio holdings than their institutional counterparts. The authors find the majority of entry and exit activity exists with small stocks. In the case of real estate mutual funds, the REITs that comprise the holdings are predominately small capitalization securities. Since the range of market capitalization of REITs is not large compared with stocks in the typical mutual fund portfolio, the effects of entry and exit on changes in holdings would be minimized.

Jegadeesh and Titman (1993) find momentum returns of securities six to twelve months after forming portfolios based on prior six-month returns. Chui, Titman and Wei (2003) examine the homogenous nature of REIT securities from 1982 to 1999 and find evidence of momentum profits of 0.89 percent per month compared to 0.42 percent for a common stock portfolio. Hung and Glascock (2008) argue that dividend growth can be used as a momentum measure. They use dividend yield as a proxy for dividend growth. Winners display higher growth than losers; this effect is more pronounced after 1992. Johnson (2002) predicts increased expected performance produces increased dividend growth rates; as a result there will be a positive correlation between dividend growth and returns. Hartzell, Mühlhofer and Titman (2007) look at real estate mutual funds from 1994 to 2005 and suggest that the use of multiple benchmarks can better explain returns.

I use market-adjusted returns and dividend yields from the previous four quarters to determine how much the prior performance influences the real estate mutual fund manager to change the composition of their portfolio. I investigate change in quarterly holdings of REITs held by mutual funds to see if they are influenced by prior period(s) market-adjusted performance and dividend yields. I examine the performance of the REITs in real estate mutual funds and compare them to certain market and asset benchmarks, similar to those used in Hartzell, Mühlhofer and Titman (2007). This study looks at effects of changes in holdings overall in real estate mutual funds. The restrictive nature of the assets in this sector of mutual funds should offer different patterns of behavior from the typical mutual fund studies. When the NYSE/AMEX/NASDAQ equal-weighted index is used as a market proxy, I find REIT holdings increase by $.44 \%$ for every $1 \%$ increase in four-quarter lagged market-adjusted return. A $1 \%$ increase in lagged dividend yields produces changes in holdings ranging from $2 \%$ to $3.5 \%$. When REIT 
performance is evaluated during the tech bubble crash period of second quarter 2002 to third quarter 2003 the projected results double.

In this area the study contributes to the literature in two ways. First, real estate mutual fund performance may be tied to fund holdings in similar fashion to traditional mutual funds. Most studies have focused on the effects of mutual fund holdings on mutual fund performance. This study looks at the persistent performance of the stocks that are held by the fund, and how it influences the manager's decision to change portfolio composition. The persistence is measured by lagged abnormal returns and changes in dividend yield. Second, real estate mutual fund performance during and after the Internet bubble has not been studied. These unique periods created two diametrically opposed economic periods ${ }^{4}$ that a defensive asset such as real estate mutual funds would be greatly affected. I provide such an analysis. In so doing, by focusing on REITs and real estate mutual funds I will provide more complete evidence on the behavior of mutual fund returns and the possible unique role of the real estate sector. Is the level of holdings in the underlying assets affected by REIT performance? I also look at another measure of REIT performance, funds from operations (FFO). Vincent (1999) examines the use of funds from operations (FFO) as opposed to earnings per share (EPS) and returns as a measure of REIT performance. FFO is determined by taking a REIT's net income as determined by GAAP (excluding net acquisition and disposition of assets) and adding back real estate depreciation ${ }^{5}$. The author looks at the information content of FFO and compares it to other information measures such as EPS, cash from operations and earnings before interest, taxes, depreciation and amortization. The author uses stock returns as a benchmark and determines that FFO has more information content than the more standard summary measures. This conclusion supports the use of FFO by NAREIT as the preferred measure of REIT performance. Performance measures used in this study will look at percentage changes in REIT price and FFO from the prior period. I find no evidence of a similar relationship between FFO-based lagged performance and change in holdings that exists with lagged returns.

The rest of the paper is presented as follows. Section II contains data, methodology and testable hypotheses. Section III contains results. Section IV concludes.

\section{DATA AND METHODOLOGY}

A mutual fund is designed to offer investors ownership of many stocks without the high transaction costs associated with individual ownership. Depending on the objective of the fund, the mutual fund will contain varying mixes of stocks, bonds, cash and real estate. In the case of real estate mutual funds, holdings will consist primarily of REITs that cover various industry sectors (office, apartments, retail, etc.). I determine the REITs that comprise each mutual fund. The REITs' stock returns are evaluated for performance over time across all funds.

Mutual fund data is obtained from Morningstar Principia files for quarterly ending periods ending March 1994 through December 2005. From this data I extract the complete holdings information ${ }^{6}$, and determine the stocks ${ }^{7}$ that are in each fund. Monthly stock return data is obtained from the University of Chicago Center of Research and Securities Prices (CRSP). These monthly returns are compounded to form quarterly returns. Price information is also obtained from CRSP. International funds will not be included in the sample ${ }^{8}$. Non-REIT holdings by funds are not included in performance tests ${ }^{9}$. Real Estate Index Funds (passively managed) are also excluded.

\footnotetext{
4 The period 1/1/1998 to 3/31/2000 provided an unprecedented period of irrational exuberance that did not center on a major conflict. This was followed by the major market correction of the tech bubble crash covering the period 4/1/2000 to 9/30/2002 .

${ }_{6}^{5}$ NAREIT Website, Glossary of Terms (2005).

${ }^{6}$ Complete holdings of a fund include the following: the stocks that are in the fund, the percentage of total net assets (market value) of each stock in the fund portfolio, the market value of each stock's holdings (price of stock at the end of a quarter times number of shares held), the number of shares held, and the change in shares held from the prior period.

${ }^{7}$ Stocks are defined as the holdings of REITs in a real estate mutual fund and any other firm in the real estate mutual fund that is publicly traded (REITs, REOCs, financial services firms, or brokerage firms).

${ }^{8}$ The stocks that are part of an international fund portfolio may not trade on NYSE, AMEX, or NASDAQ, so return information may be unavailable.

${ }^{9}$ This study is centered on the performance and return persistence of REITs, and most of the stocks held by the real estate mutual funds are REITs.
} 
I seek to determine how the quarterly performance of a particular REIT's stock over the previous year and changes in dividend policy affects the percentage of the REIT held by a particular mutual fund. The following hypotheses are tested:

H1: The change in holdings of a REIT in a real estate mutual fund is not affected by lagged market-adjusted performance.

H2: The change in holdings of a REIT in a real estate mutual fund is not affected by lagged dividend yields.

I test the hypotheses by estimating the following relationship:

$\Delta H l d_{\mathrm{it}}=\alpha_{0 \mathrm{i}}+\sum_{\mathrm{k}=1}^{4} \beta_{\mathrm{i}}\left(\mathrm{R}_{\mathrm{it}-\mathrm{k}}-\mathrm{R}_{\mathrm{m}-\mathrm{k}}\right)+\sum_{\mathrm{k}=1}^{4} \beta_{\mathrm{i}}\left(\mathrm{DYLD}_{\mathrm{it}-\mathrm{k}}\right)+\varepsilon_{\mathrm{it}}$

where:

$\mathrm{R}_{\mathrm{it}-\mathrm{k}}=$ Quarterly return of REIT $i$ for $k=1$ to $k=4$;

$\mathrm{R}_{\mathrm{mt}-\mathrm{k}}=$ Quarterly return on a market index portfolio for $k=1$ to $k=4$;

$\mathrm{DYLD}_{\mathrm{it}-\mathrm{k}}=$ Quarterly dividend yield of REIT $i$ for $k=1$ to $k=4$;

$\Delta H l d_{\mathrm{it}}=$ Change in percentage holdings ${ }^{10}$ of REIT $i$ from the end of quarter $t-1$ to the end of quarter $t$;

$\mathrm{R}_{\mathrm{it}-\mathrm{k}}-\mathrm{R}_{\mathrm{mt}-\mathrm{k}}=$ Quarterly market-adjusted return for $k=1$ to $k=4$.

Dividend information is obtained from COMPUSTAT. Equation (1) is a time-series regression estimated for each REIT in each fund. Within a fund, for each quarter changes in holdings for each REIT related to the prior four quarters respective REIT return in excess of a benchmark are measured. The dividend yield $\left(\mathrm{D}_{1} / \mathrm{P}_{0}\right.$ : dividend per share this quarter divided by price per share previous quarter) for the prior four quarters is also calculated. Equation (1) is then estimated. The estimated coefficients are $\alpha_{0}, \beta_{1}$, and $\beta_{2} ; \varepsilon_{\mathrm{it}}$ is an error term. Funds must have a minimum of twelve consecutive quarters of data. I use the NYSE/AMEX/NASDAQ equal-weighted and value-weighted return and the equity REIT composite equal-weighted and value-weighted index as different proxies for the market index. If the coefficients are significantly positive then this would indicate that changes in holdings of stocks are directly related to the stock's prior performance.

The addition of REITs to a real estate mutual fund portfolio or removal of REITs from a real estate mutual fund can distort the effects of prior performance based trading. For example, suppose a manager has $\$ 100,000$ of REIT 1 and $\$ 50,000$ of REIT 2 in his portfolio. The percentage holdings in the fund are $67 \%$ and $33 \%$, respectively. Strong prior performance of both REITs moves the advisor to purchase $\$ 200,000$ of REIT 1 and $\$ 100,000$ of REIT 2. However, $\$ 450,000$ of REIT 3 is purchased. The new percentage holding figures are $33 \%$ of REIT $1,17 \%$ of REIT 2, and $50 \%$ of REIT 3 . So, momentum trading produces a negative value of $\Delta H l d$ in REIT 1 and REIT 2 . The decision of an advisor to sell off a REIT can produce similar effects. In a manner similar to Badrinath and Wahal (2002), I will identify the REITs that initially enter and completely exit the funds in a given quarter. If $\left(H l d_{\mathrm{it}}-H l d_{\mathrm{it}-}\right.$ $\left.{ }_{1}\right)=H l d_{\mathrm{it}}$, the REIT is in an entry position. If $\left(H l d_{\mathrm{it}}-H l d_{\mathrm{it}-1}\right)=-H l d_{\mathrm{it}-1}$, the REIT is in an exit position. Equation (1) will be estimated:

1) over all REITs,

2) without entry and exit REITs,

The results generated without entry and exit REITs should offer the most accurate measure of momentum effects.

Shares of REITs held by each real estate mutual fund could be used as an alternative measure. Changes in the number of REIT shares held offers a method to measure how a manager reacts to REIT prior performance without giving misleading changes in percentage assets held when entry and exit REITs are included. Significant

${ }^{10} \Delta H l d_{\mathrm{it}}=\left(H L D_{\mathrm{it}}-H L D_{\mathrm{it}-1}\right)$, where $H L D$ is the percentage of total net assets (market value) of each REIT in a fund's portfolio. However, entry and exit of REITs in the respective portfolios can give misleading results. The shares of each REIT held by the fund can be used as an alternative measure. 
changes in REIT prices can cause markedly different results and in some cases the regression may cause a reversal in $\operatorname{sign}^{11}$.

\section{Performance Based on Funds from Operations (FFO)}

FFO (the industry accepted measure of REIT performance) data are obtained from SNL Financial. FFO is determined by taking a REIT's net income as determined by GAAP (excluding net acquisition and disposition of assets) and adding back real estate depreciation. Performance based on FFO is denoted FFOP, expressed by the following formula:

$\mathrm{FFOP}_{\mathrm{t}}=\left(\mathrm{FFO}_{\mathrm{t}}-\mathrm{FFO}_{\mathrm{t}-1}\right) / \mathrm{FFO}_{\mathrm{t}-1}$

The effect of performance on change in holdings is determined thusly:

$\Delta H l d_{\mathrm{it}}=\alpha_{0 \mathrm{i}}+\sum_{\mathrm{k}=1}^{4} \beta_{\mathrm{i}}\left(\mathrm{FFOP}_{\mathrm{it}-\mathrm{k}}-\mathrm{FFOP}_{\mathrm{m}-\mathrm{k}}\right)+\sum_{\mathrm{k}=1}^{4} \beta_{\mathrm{i}}\left(\mathrm{DYLD}_{\mathrm{i} t \mathrm{k}}\right)+\varepsilon_{\mathrm{it}}$

where:

$\mathrm{FFOP}_{\text {it-k }}=$ Quarterly FFO performance of REIT $i$ for $k=1$ to $k=4$;

$\mathrm{FFOP}_{\mathrm{mt}-\mathrm{k}}=$ Quarterly equal-weighted FFO performance of equity REITs for $k=1$ to $k=4^{12}$;

I will account for the effects of entry and exit REITs in a manner similar to Badrinath and Wahal (2002).

A similar analysis will be made combining the ex-ante and ex-post measures to determine which gives the largest contribution to quarterly change in holdings:

$\Delta H l d_{\mathrm{it}}=\alpha_{0 \mathrm{i}}+\sum_{\mathrm{k}=1}^{4} \beta_{\mathrm{i}}\left(\mathrm{R}_{\mathrm{it}-\mathrm{k}}-\mathrm{R}_{\mathrm{m}-\mathrm{k}}\right)+\sum_{\mathrm{k}=1}^{4} \beta_{\mathrm{i}}\left(\right.$ FFOP $\left._{\mathrm{it}-\mathrm{k}}-\mathrm{FFOP}_{\mathrm{m} t \mathrm{k}}\right)+\sum_{\mathrm{k}=1}^{4} \beta_{\mathrm{i}}\left(\mathrm{DYLD}_{\mathrm{it}-\mathrm{k}}\right)+\varepsilon_{\mathrm{it}} ;$

\section{RESULTS}

\section{Descriptive Statistics}

The analysis of fund behavior and the performance of REITs held by the funds are shown in Table 1. Panel A looks at REITs. The average market capitalization of equity REITs has increased steadily over the twelve-year period (1994 - 2005) from over $\$ 1.32$ billion among 81 REITs to $\$ 4.18$ billion among 166 REITs. Average quarterly returns approaching 16\% appear at the end of December 1996 and June 2003. The greatest number of REIT IPO's occurred from 1995 to 1997; the average quarterly returns in 1996 to 1998 reflect the market's reaction to this period of tremendous REIT activity. The average quarterly returns from 1998-2000 ran counter to the equity performance during the tech bubble period. Average market-adjusted returns are negative from the fourth quarter 1998 to first quarter 2000. REIT returns improved during the bear market period of mid-2000 to the end of 2002. There are large average quarterly market-adjusted return fluctuations however, ranging from $+20.72 \%$ to $-19.89 \%{ }^{13}$

\footnotetext{
${ }^{11}$ For example, suppose a manager has 100 shares of REIT 1 and 50 shares of REIT 2 in his portfolio. The percentage holdings in the fund are $67 \%$ and $33 \%$, respectively. If REIT 1 has a share price of $\$ 20$ and REIT 2 has a share price of $\$ 30$ then percentage holdings become $57 \%$ and $43 \%$. Strong prior performance of both REITs moves the advisor to purchase 200 shares of REIT 1 at $\$ 40$ and 100 shares of REIT 2 at $\$ 35$. However, 400 shares of REIT 3 are purchased at $\$ 10$. The new percentage holding figures are $55 \%$ of REIT 1, 25\% of REIT 2, and $20 \%$ of REIT 3. Share holdings show 35\% of REIT 1, 18\% of REIT 2, and $47 \%$ of REIT 3.

${ }^{12} \mathrm{FFOP}_{\mathrm{mt}}=\left(\mathrm{FFO}_{\mathrm{mt}}-\mathrm{FFO}_{\mathrm{mt}-1}\right) / \mathrm{FFO}_{\mathrm{mt}-1}$. $\mathrm{FFO}_{\mathrm{mt}}$ is the equal-weighted composite equity REIT FFO. FFO is determined by taking a REIT's net income as determined by GAAP (excluding net acquisition and disposition of assets) and adding back real estate depreciation. These are quarterly figures obtained from COMPUSTAT.

13 The CRSP NYSE/AMEX/NASDAQ equal-weighted market capitalization index is used. Later analysis will use a more industry related index such as the NAREIT (National Association of Real Estate Investment Trusts) composite index.
} 
The share price of REITs has moved in similar fashion; only in late 2003 has the price level of REITs returned to those of the pre-tech bubble period. A typical REIT purchased by a fund manager will be about $2 \%$ of the total fund portfolio, as shown in the average percentage hold column.

Table 1

Descriptive Statistics

Quarterly results of REITs residing in real estate mutual funds are shown. In Panel A, Market capitalization and return figures are obtained from CRSP. Average return represents all equity REIT returns. Market-adjusted return is $\left(R_{i}-R_{m}\right)$, where $R_{m}$ is the CRSP NYSE/AMEX/Nasdaq equal-weighted portfolio quarterly return. Average price per share covers all equity REITs. Average percentage holding is the percentage value of a REIT relative to total assets held by a real estate mutual fund. In Panel B, average NAV represents the net asset value per share of all real estate mutual funds. Average returns represent quarterly returns of mutual funds taken from Morningstar Principia database.

\section{Panel A: REITs in Mutual Funds}

\begin{tabular}{|c|c|c|c|c|c|c|}
\hline $\begin{array}{l}\text { Period } \\
\text { End }\end{array}$ & $\begin{array}{c}\text { Number of } \\
\text { REITs }\end{array}$ & $\begin{array}{c}\text { Average Market } \\
\text { Capitalization (\$MM) } \\
\end{array}$ & $\begin{array}{c}\text { Average } \\
\text { Return }(\%)\end{array}$ & $\begin{array}{c}\text { Average Market- } \\
\text { Adjusted Return (\%) }\end{array}$ & $\begin{array}{c}\text { Average } \\
\text { Price }\end{array}$ & $\begin{array}{c}\text { Average Percent } \\
\text { Holding }\end{array}$ \\
\hline Mar-94 & 86 & $\$ 1,318$ & 2.86 & 3.76 & $\$ 19.11$ & 1.58 \\
\hline Jun-94 & 94 & $\$ 1,181$ & 3.46 & 7.49 & $\$ 18.69$ & 1.68 \\
\hline Sep-94 & 99 & $\$ 1,158$ & 0.42 & -5.41 & $\$ 17.88$ & 1.78 \\
\hline Dec-94 & 101 & $\$ 1,180$ & -2.07 & 3.60 & $\$ 16.98$ & 1.75 \\
\hline Mar-95 & 101 & $\$ 1,238$ & 3.47 & -4.30 & $\$ 17.12$ & 1.74 \\
\hline Jun-95 & 103 & $\$ 1,275$ & 5.77 & -4.24 & $\$ 17.42$ & 1.74 \\
\hline Sep-95 & 104 & $\$ 1,413$ & 5.68 & -6.04 & $\$ 18.14$ & 1.68 \\
\hline Dec-95 & 104 & $\$ 1,564$ & 3.98 & 5.65 & $\$ 19.24$ & 1.74 \\
\hline Mar-96 & 105 & $\$ 1,659$ & 6.03 & -3.35 & $\$ 19.87$ & 1.68 \\
\hline Jun-96 & 106 & $\$ 1,809$ & 3.46 & -5.36 & $\$ 19.04$ & 1.58 \\
\hline Sep-96 & 107 & $\$ 1,902$ & 6.77 & 7.76 & $\$ 20.91$ & 1.68 \\
\hline Dec-96 & 111 & $\$ 2,065$ & 15.67 & 15.41 & $\$ 24.24$ & 1.88 \\
\hline Mar-97 & 112 & $\$ 2,090$ & 1.67 & 1.57 & $\$ 23.55$ & 1.87 \\
\hline Jun-97 & 116 & $\$ 2,521$ & 5.99 & -4.77 & $\$ 24.57$ & 1.74 \\
\hline Sep-97 & 119 & $\$ 2,697$ & 11.54 & -5.04 & $\$ 26.17$ & 1.74 \\
\hline Dec-97 & 123 & $\$ 2,812$ & 1.69 & 8.70 & $\$ 26.16$ & 1.68 \\
\hline Mar-98 & 126 & $\$ 3,197$ & 1.74 & -10.98 & $\$ 23.81$ & 1.58 \\
\hline Jun-98 & 129 & $\$ 3,245$ & -5.06 & -0.17 & $\$ 23.97$ & 1.68 \\
\hline Sep-98 & 130 & $\$ 2,845$ & -7.02 & 13.18 & $\$ 20.78$ & 1.78 \\
\hline Dec-98 & 130 & $\$ 3,432$ & -0.63 & -14.41 & $\$ 20.75$ & 1.75 \\
\hline Mar-99 & 131 & $\$ 3,589$ & -4.78 & -6.62 & $\$ 18.93$ & 1.86 \\
\hline Jun-99 & 132 & $\$ 3,718$ & 12.44 & -2.09 & $\$ 21.04$ & 1.89 \\
\hline Sep-99 & 132 & $\$ 3,774$ & -7.25 & -3.60 & $\$ 19.25$ & 1.91 \\
\hline Dec-99 & 133 & $\$ 4,631$ & -1.64 & -19.89 & $\$ 18.88$ & 1.93 \\
\hline Mar-00 & 133 & $\$ 4,675$ & 2.66 & -15.01 & $\$ 18.64$ & 2.04 \\
\hline Jun-00 & 134 & $\$ 4,813$ & 8.70 & 15.97 & $\$ 19.08$ & 2.10 \\
\hline Sep-00 & 134 & $\$ 5,214$ & 7.23 & 7.52 & $\$ 19.66$ & 2.12 \\
\hline Dec-00 & 134 & $\$ 4,531$ & 2.41 & 20.72 & $\$ 20.34$ & 2.18 \\
\hline Mar-01 & 134 & $\$ 4,077$ & 5.88 & 0.75 & $\$ 20.14$ & 2.08 \\
\hline Jun-01 & 134 & $\$ 4,692$ & 12.02 & -3.21 & $\$ 22.15$ & 2.08 \\
\hline Jun-02 & 134 & $\$ 3,411$ & 4.88 & 13.36 & $\$ 23.99$ & 2.17 \\
\hline Sep-02 & 136 & $\$ 2,916$ & -8.60 & 9.18 & $\$ 22.21$ & 2.18 \\
\hline Dec-02 & 138 & $\$ 2,863$ & -0.12 & -12.00 & $\$ 21.35$ & 2.08 \\
\hline Mar-03 & 140 & $\$ 2,930$ & 0.64 & 1.26 & $\$ 20.94$ & 2.09 \\
\hline Jun-03 & 140 & $\$ 3,266$ & 15.62 & -15.44 & $\$ 23.40$ & 2.12 \\
\hline Sep-03 & 143 & $\$ 3,699$ & 9.50 & -4.52 & $\$ 25.03$ & 2.03 \\
\hline Dec-03 & 145 & $\$ 3,645$ & 10.71 & -5.88 & $\$ 26.78$ & 2.12 \\
\hline Mar-04 & 147 & $\$ 3,785$ & 10.28 & 1.56 & $\$ 29.17$ & 2.18 \\
\hline Jun-04 & 150 & $\$ 3,867$ & -5.44 & -3.51 & $\$ 26.76$ & 2.08 \\
\hline Sep-04 & 154 & $\$ 3,968$ & 7.53 & 9.14 & $\$ 28.17$ & 2.02 \\
\hline Dec-04 & 164 & $\$ 4,181$ & 13.67 & -2.41 & $\$ 30.36$ & 2.12 \\
\hline Mar-05 & 168 & $\$ 4,378$ & -5.76 & -0.92 & $\$ 27.40$ & 2.10 \\
\hline Jun-05 & 170 & $\$ 4,533$ & 11.60 & 9.37 & $\$ 29.03$ & 2.02 \\
\hline Sep-05 & 172 & $\$ 4,765$ & 2.27 & -3.49 & $\$ 31.78$ & 2.08 \\
\hline$\frac{1}{\text { Dec-05 }}$ & 174 & $\$ 5,268$ & 0.97 & 0.20 & $\$ 32.17$ & 2.23 \\
\hline
\end{tabular}


The mutual fund activity is shown in Panel B. The number of real estate mutual funds has grown from 34 at the end of 1994 to 259 at the end of 2005 . The average price level of mutual funds (measured by NAV) is at a high of $\$ 18.57$ in 1997 , drops to a low of $\$ 10.16$ in 1999 , and shows steady increases from 2001 to a high of $\$ 23.69$ at the end of 2004 . The quarterly returns of mutual funds show similar patterns to the REIT returns.

\begin{tabular}{|c|c|c|c|}
\hline \multicolumn{4}{|c|}{ Panel B: Real Estate Mutual Funds } \\
\hline Period End & Number of Funds & Average NAV & Average Return (\%) \\
\hline Mar-94 & 34 & $\$ 12.31$ & 2.74 \\
\hline Jun-94 & 35 & $\$ 13.98$ & 11.23 \\
\hline Sep-94 & 35 & $\$ 14.12$ & 5.17 \\
\hline Dec-94 & 35 & $\$ 14.34$ & 1.83 \\
\hline Mar-95 & 43 & $\$ 13.98$ & -3.20 \\
\hline Jun-95 & 44 & $\$ 14.58$ & 4.30 \\
\hline Sep-95 & 44 & $\$ 15.01$ & 3.20 \\
\hline Dec-95 & 46 & $\$ 14.77$ & -2.40 \\
\hline Mar-96 & 46 & $\$ 14.55$ & -1.40 \\
\hline Jun-96 & 46 & $\$ 14.79$ & 1.40 \\
\hline Sep-96 & 46 & $\$ 13.04$ & -12.50 \\
\hline Dec-96 & 47 & $\$ 15.12$ & 16.04 \\
\hline Mar-97 & 50 & $\$ 15.75$ & 2.06 \\
\hline Jun-97 & 62 & $\$ 16.22$ & 1.23 \\
\hline Sep-97 & 54 & $\$ 18.57$ & 14.14 \\
\hline Dec-97 & 62 & $\$ 16.22$ & 1.13 \\
\hline Mar-98 & 69 & $\$ 16.04$ & -0.08 \\
\hline Jun-98 & 85 & $\$ 14.17$ & -5.08 \\
\hline Sep-98 & 97 & $\$ 12.18$ & -12.44 \\
\hline Dec-98 & 102 & $\$ 11.61$ & -0.60 \\
\hline Mar-99 & 113 & $\$ 10.77$ & -4.67 \\
\hline Jun-99 & 118 & $\$ 11.87$ & 11.61 \\
\hline Sep-99 & 122 & $\$ 10.16$ & -9.26 \\
\hline Dec-99 & 122 & $\$ 10.42$ & 0.02 \\
\hline Mar-00 & 126 & $\$ 10.94$ & 2.19 \\
\hline Jun-00 & 125 & $\$ 11.66$ & 10.86 \\
\hline Sep-00 & 130 & $\$ 12.59$ & 6.95 \\
\hline Dec-00 & 135 & $\$ 13.52$ & 3.03 \\
\hline Mar-01 & 146 & $\$ 13.22$ & -1.56 \\
\hline Jun-01 & 137 & $\$ 14.61$ & 9.70 \\
\hline Sep-01 & 131 & $\$ 14.10$ & -3.10 \\
\hline Dec-01 & 140 & $\$ 14.52$ & 4.71 \\
\hline Mar-02 & 147 & $\$ 15.73$ & 7.91 \\
\hline Jun-02 & 146 & $\$ 15.97$ & 4.74 \\
\hline Sep-02 & 148 & $\$ 14.35$ & -8.92 \\
\hline Dec-02 & 143 & $\$ 14.18$ & 0.56 \\
\hline Mar-03 & 155 & $\$ 14.10$ & 1.40 \\
\hline Jun-03 & 160 & $\$ 15.93$ & 12.56 \\
\hline Sep-03 & 166 & $\$ 16.91$ & 9.27 \\
\hline Dec-03 & 169 & $\$ 22.58$ & 2.69 \\
\hline Mar-04 & 188 & $\$ 22.92$ & 2.68 \\
\hline Jun-04 & 198 & $\$ 19.70$ & -5.54 \\
\hline Sep-04 & 212 & $\$ 22.63$ & 2.66 \\
\hline Dec-04 & 219 & $\$ 23.69$ & 16.12 \\
\hline Mar-05 & 219 & $\$ 23.41$ & 9.37 \\
\hline Jun-05 & 218 & $\$ 23.12$ & 2.62 \\
\hline Sep-05 & 220 & $\$ 23.02$ & 2.63 \\
\hline Dec-05 & 259 & $\$ 22.89$ & 2.60 \\
\hline
\end{tabular}




\section{Prior REIT Performance and Change in Mutual Fund Holdings}

I hypothesize the prior performance of REITs has a positive relationship with the change in holdings within a real estate mutual fund. A REIT that does well will have more shares purchased by a fund manager, subsequently increasing the percentage of the REIT held by the fund.

The effects of lagged abnormal returns and dividend yields on the change in holdings of a REIT by a mutual fund are shown in Table 2. Equation (1) is estimated for each fund. Using a Fama and MacBeth (1973) approach, regression coefficients are averaged across funds to produce the reported values in Table II. The standard error of the fund coefficients is employed to produce reported t-statistics. Panel A uses the NYSE/AMEX/NASDAQ equal-weighted returns as a market proxy. I find evidence of a four quarter lagged market-adjusted return affecting changes in holdings, keeping lagged dividend yield constant. The expected positive sign is evident. An increase of one percent in market-adjusted return produces a $0.438 \%$ increase in holdings. There is a significant negative intercept that suggests a decrease in the average holding of a REIT by a mutual fund of $0.1835 \%$ if all independent variables were zero. This result is significant at the $1 \%$ level. The lagged dividend yield variables show positive and significant results with the exception of dividend yields four quarters prior to the period in question. An increase of one percent in dividend yield produces on average a $2.01 \%$ to $3.69 \%$ increase in the percent holdings of a REIT in the period one quarter to three quarters prior to the current quarter. The one-quarter lagged result is significant at the 5\% level; the two quarter and three quarter lagged result is significant at the $1 \%$ level.

Panel B uses the composite equity REIT equal-weighted returns as a market proxy. I find no evidence of lagged market-adjusted returns affecting changes in holdings, keeping lagged dividend yield constant. The expected positive sign is evident. There is a significant negative intercept that suggests a decrease in the average holding of a REIT by a mutual fund of $0.1716 \%$ if all independent variables were zero. This result is significant at the $1 \%$ level. Lagged one quarter dividend yield is significant at the 5\% level with a projected change in holdings of $1.88 \%$. Lagged two and three quarter dividend yield is significant at the $1 \%$ level with projected change in holdings from $3.14 \%$ to $3.70 \%$. Panel $\mathrm{C}$ and panel D show similar results using NYSE/AMEX/NASDAQ and REIT composite value-weighted returns as a market proxy. $\mathrm{R}^{2}$ measures range from 0.41 (Panel A) to 0.44 (Panel D).

Table 2

Prior REIT Performance and Change in Mutual Fund Holdings

The change in quarterly mutual fund holdings is the result of the following relationship:

$\Delta H l d_{\mathrm{it}}=\alpha_{0 \mathrm{i}}+\sum_{\mathrm{k}=1}^{4} \beta_{\mathrm{i}}\left(\mathrm{R}_{\mathrm{i} \cdot \mathrm{k}}-\mathrm{R}_{\mathrm{m} \cdot \mathrm{k}}\right)+\sum_{\mathrm{k}=1}^{4} \beta_{\mathrm{i}}\left(\mathrm{DYLD}_{\mathrm{i} \cdot \mathrm{k}}\right)+\varepsilon_{\mathrm{it}} ;$

where $\mathrm{R}_{\mathrm{it}-\mathrm{k}}=$ return of stock $i$ for quarter $t-k(k=1$ to 4$), \mathrm{R}_{\mathrm{mt}-\mathrm{k}}=$ return on a market index portfolio for quarter $t-k,(\mathrm{k}=1$ to 4$)$, $\mathrm{DYLD}_{\mathrm{it}-\mathrm{k}}=$ dividend yield for quarter $t-k\left(k=1\right.$ to 4 and $\Delta H l d_{\mathrm{it}}=$ change in percentage holdings of stock $i$ from quarter $t-1$ to quarter $t$ ). The CRSP NYSE/AMEX/Nasdaq equal-weighted portfolio quarterly returns serve as the market proxy in Panel A; the Composite equal-weighted equity REIT quarterly returns serve as the market proxy in Panel B. The CRSP NYSE/AMEX/Nasdaq value-weighted portfolio quarterly returns serve as the market proxy in Panel C; the Composite valueweighted equity REIT quarterly returns serve as the market proxy in Panel D.

\begin{tabular}{|l|c|c|c|}
\hline \multicolumn{1}{|c|}{ Pariable } & Coefficient & t-statistic & probability $<\mathbf{t}$ \\
\hline intercept & -0.1835 & $* * *-6.14$ & $<0.0001$ \\
\hline $\mathrm{R}_{\mathrm{it}-1}-\mathrm{R}_{\mathrm{mt}-1}$ & 0.0206 & 0.10 & 0.9213 \\
\hline $\mathrm{R}_{\mathrm{it}-2}-\mathrm{R}_{\mathrm{mt}-2}$ & 0.0426 & 0.15 & 0.8798 \\
\hline $\mathrm{R}_{\mathrm{it}-3}-\mathrm{R}_{\mathrm{mt}-3}$ & 0.3630 & 1.29 & 0.1967 \\
\hline $\mathrm{R}_{\mathrm{it}-4}-\mathrm{R}_{\mathrm{mt}-4}$ & 0.4380 & $* * 2.10$ & 0.0354 \\
\hline $\mathrm{DYLD}_{\mathrm{it}-1}$ & 2.0100 & $* 1.90$ & 0.0577 \\
\hline DYLD $_{\mathrm{it}-2}$ & 3.0600 & $* * * 2.81$ & 0.0049 \\
\hline DYLD $_{\mathrm{it}-3}$ & 3.6890 & $* * * 3.39$ & 0.0007 \\
\hline DYLD $_{\mathrm{it}-4}$ & 1.1750 & 1.11 & 0.2661 \\
\hline
\end{tabular}




\begin{tabular}{|l|c|c|c|}
\hline \multicolumn{1}{|c|}{ Panel B: Composite Equal-Weighted Equity REIT Returns as Market Proxy $\left(\mathbf{R}^{2}=\mathbf{0 . 4 2}\right)$} & probability $<\mathbf{t}$ \\
\hline \multicolumn{1}{|c|}{ Variable } & Coefficient & $* * *-5.71$ & $<0.0001$ \\
\hline intercept & -0.1716 & 0.06 & 0.9506 \\
\hline $\mathrm{R}_{\mathrm{it}-1}-\mathrm{R}_{\mathrm{mt}-1}$ & 0.0137 & 0.29 & 0.7739 \\
\hline $\mathrm{R}_{\mathrm{it}-2}-\mathrm{R}_{\mathrm{mt}-2}$ & 0.0854 & 0.13 & 0.8971 \\
\hline $\mathrm{R}_{\mathrm{it}-3}-\mathrm{R}_{\mathrm{mt}-3}$ & 0.0384 & 0.53 & 0.5992 \\
\hline $\mathrm{R}_{\mathrm{it}-4}-\mathrm{R}_{\mathrm{mt}-4}$ & 0.1160 & $* 1.78$ & 0.0751 \\
\hline $\mathrm{DYLD}_{\mathrm{it}-1}$ & 1.8850 & $* * * 2.89$ & 0.0038 \\
\hline $\mathrm{DYLD}_{\mathrm{it}-2}$ & 3.1440 & $* * * 3.41$ & 0.0007 \\
\hline DYLD $_{\mathrm{it}-3}$ & 3.7000 & 1.09 & 0.2762 \\
\hline DYLD $_{\mathrm{it}-4}$ & 1.1500 & & \\
\hline
\end{tabular}

\begin{tabular}{|c|c|c|c|}
\hline \multicolumn{4}{|c|}{ Panel C: NYSE/AMEX/Nasdaq Value-Weighted Portfolio Return as Market Proxy $\left(R^{2}=0.43\right)$} \\
\hline Variable & Coefficient & t-statistic & probability $<\mathrm{t}$ \\
\hline intercept & -0.1845 & $* * *-6.17$ & $<0.0001$ \\
\hline $\mathrm{R}_{\mathrm{it}-1}-\mathrm{R}_{\mathrm{mt}-1}$ & 0.1320 & 0.42 & 0.6744 \\
\hline $\mathrm{R}_{\mathrm{it}-2}-\mathrm{R}_{\mathrm{mt}-2}$ & 0.2130 & 0.52 & 0.6000 \\
\hline $\mathrm{R}_{\mathrm{it}-3}-\mathrm{R}_{\mathrm{mt}-3}$ & 0.0523 & 0.13 & 0.8967 \\
\hline $\mathrm{R}_{\mathrm{it}-4}-\mathrm{R}_{\mathrm{mt}-4}$ & 0.0336 & 0.11 & 0.9147 \\
\hline DYLD $_{\text {it-1 }}$ & 2.1510 & $* * 2.03$ & 0.0419 \\
\hline DYLD $_{\mathrm{it}-2}$ & 3.0060 & $* * * 2.77$ & 0.0057 \\
\hline DYLD $_{\text {it-3 }}$ & 3.6260 & $* * * 3.34$ & 0.0009 \\
\hline DYLD $_{\text {it-4 }}$ & 1.1800 & 1.12 & 0.2636 \\
\hline \multicolumn{4}{|c|}{ Panel D: Composite Value-Weighted Equity REIT Returns as Market Proxy $\left(\mathbf{R}^{2}=0.41\right)$} \\
\hline Variable & Coefficient & t-statistic & probability $<\mathrm{t}$ \\
\hline intercept & -0.1810 & $* * * 6.05$ & $<0.0001$ \\
\hline $\mathrm{R}_{\mathrm{it}-1}-\mathrm{R}_{\mathrm{mt}-1}$ & 0.0546 & 0.27 & 0.7867 \\
\hline $\mathrm{R}_{\mathrm{it}-2}-\mathrm{R}_{\mathrm{mt}-2}$ & 0.1620 & 0.61 & 0.5451 \\
\hline$R_{\mathrm{it}-3}-\mathrm{R}_{\mathrm{mt}-3}$ & 0.0282 & 0.11 & 0.9161 \\
\hline $\mathrm{R}_{\mathrm{it}-4}-\mathrm{R}_{\mathrm{mt}-4}$ & 0.0882 & 0.44 & 0.6571 \\
\hline DYLD $_{\text {it-1 }}$ & 2.0100 & $* 1.90$ & 0.0575 \\
\hline DYLD $_{\text {it-2 }}$ & 3.0630 & $* * * 2.82$ & 0.0048 \\
\hline DYLD $_{\text {it-3 }}$ & 3.6830 & $* * * 3.39$ & 0.0007 \\
\hline DYLD $_{\text {it }-4}$ & 1.1510 & 1.09 & 0.2758 \\
\hline
\end{tabular}

* Significance at $10 \%$ level

**Significance at $5 \%$ level

$* * *$ Significance at $1 \%$ level

\section{Effects without Entry and Exit REITs}

The results generated without entry and exit REITs should offer a more accurate measure of effects on changes in percent holdings. The mutual fund manager would be most concerned with how holdings would change with REITs most consistently present in their portfolios. I use Table 3 to display the appropriate results.

Panel A uses the NYSE/AMEX/NASDAQ equal-weighted returns as a market proxy. I find evidence of a four quarter lagged market-adjusted return affecting changes in holdings, keeping lagged dividend yield constant. The expected positive sign is evident. An increase of one percent in market-adjusted return produces a $0.446 \%$ increase in holdings. There is a significant negative intercept that suggests a decrease in the average holding of a REIT by a mutual fund of $0.2303 \%$ if all independent variables were zero. This result is significant at the $1 \%$ level. The lagged dividend yield variables show positive and significant results with the exception of dividend yields two and four quarters prior to the period in question. An increase of one percent in dividend yield produces on average a $2.15 \%$ and $3.38 \%$ increase in the percent holdings of a REIT in the period one quarter and three quarters prior to the current quarter respectively. The one quarter lagged result is significant at the 5\% level; the three quarter lagged result is significant at the $1 \%$ level.

Panel B uses the composite equity REIT equal-weighted returns as a market proxy. I find no evidence of lagged market-adjusted returns affecting changes in holdings, keeping lagged dividend yield constant. The expected 
positive sign is evident. There is a significant negative intercept that suggests a decrease in the average holding of a REIT by a mutual fund of $0.2218 \%$ if all independent variables were zero. This result is significant at the $1 \%$ level. Lagged one quarter dividend yield is significant at the 5\% level with a projected change in holdings of $2.08 \%$. Lagged three quarter dividend yield is significant at the $1 \%$ level with projected change in holdings of $3.37 \%$. Panel $\mathrm{C}$ and panel D show similar results using NYSE/AMEX/NASDAQ and REIT composite value-weighted returns as a market proxy. $\mathrm{R}^{2}$ values range from 0.38 (Panel D) to 0.40 (Panel A).

Overall, REITs that remain in the real estate mutual fund portfolio from quarter to quarter have a greater contribution to the change in percentage holdings of REITs in a fund. This conclusion is most evident when dividend yield in the prior quarter is used as a point of decision making by the real estate mutual fund manager.

Table 3

Prior REIT Performance and Change in

Mutual Fund Holdings (No Entry and Exit REITs)

The change in quarterly mutual fund holdings is the result of the following relationship:

$\Delta H l d_{\mathrm{it}}=\alpha_{0 \mathrm{i}}+\sum_{\mathrm{k}=1}^{4} \beta_{\mathrm{i}}\left(\mathrm{R}_{\mathrm{i}-\mathrm{k}}-\mathrm{R}_{\mathrm{m}-\mathrm{k}}\right)+\sum_{\mathrm{k}=1}^{4} \beta_{\mathrm{i}}\left(\mathrm{DYLD}_{\mathrm{it}-\mathrm{k}}\right)+\varepsilon_{\mathrm{it}}$

where $\mathrm{R}_{\mathrm{it}-\mathrm{k}}=$ return of stock $i$ for quarter $t-k(k=1$ to 4$), \mathrm{R}_{\mathrm{mt}-\mathrm{k}}=$ return on a market index portfolio for quarter $t-k,(\mathrm{k}=1$ to 4$)$, $\mathrm{DYLD}_{\mathrm{it}-\mathrm{k}}=$ dividend yield for quarter $t-k(k=1$ to 4$)$ and $\Delta H l d_{\mathrm{it}}=$ change in percentage holdings of stock $i$ from quarter $t-1$ to quarter $t$. I analyze the effects of REITs initially entering and completely exiting the mutual fund portfolio. If $\left(H l d_{\mathrm{it}}-H l d_{\mathrm{it}-1}\right)=$ $H l d_{\mathrm{it}}$, the REIT is in an entry position. If $\left(H l d_{\mathrm{it}}-H l d_{\mathrm{it}-1}\right)=-H l d_{\mathrm{it}-1}$, the REIT is in an exit position. This table looks at the sample when entry and exit REITs are excluded. The CRSP NYSE/AMEX/Nasdaq equal-weighted portfolio quarterly returns serve as the market proxy in Panel A; the CRSP NYSE/AMEX/Nasdaq value-weighted portfolio quarterly returns serve as the market proxy in Panel B. The Composite equity REIT equal-weighted portfolio quarterly returns serve as the market proxy in Panel C; the Composite equity REIT value-weighted portfolio quarterly returns serve as the market proxy in Panel D.

\begin{tabular}{|c|c|c|c|}
\hline \multicolumn{4}{|c|}{ Panel A: NYSE/AMEX/Nasdaq Equal-Weighted Portfolio Return as Market Proxy $\left(\mathbf{R}^{2}=0.40\right)$} \\
\hline Variable & Coefficient & t-statistic & probability $<\mathrm{t}$ \\
\hline intercept & -0.2303 & $* * * 7.85$ & $<0.0001$ \\
\hline $\mathrm{R}_{\mathrm{it}-1}-\mathrm{R}_{\mathrm{mt}-1}$ & 0.0807 & 0.38 & 0.7012 \\
\hline $\mathrm{R}_{\mathrm{it}-2}-\mathrm{R}_{\mathrm{mt}-2}$ & 0.0036 & 0.01 & 0.9898 \\
\hline $\mathrm{R}_{\mathrm{it}-3}-\mathrm{R}_{\mathrm{mt}-3}$ & 0.0264 & 0.93 & 0.3508 \\
\hline $\mathrm{R}_{\mathrm{it}-4}-\mathrm{R}_{\mathrm{mt}-4}$ & 0.4460 & $* * 2.18$ & 0.0294 \\
\hline $\mathrm{DYLD}_{\mathrm{it}-1}$ & 2.1530 & $* * 2.06$ & 0.0391 \\
\hline DYLD $_{\text {it-2 }}$ & 1.1760 & 1.09 & 0.2772 \\
\hline DYLD $_{\text {it-3 }}$ & 3.3760 & $* * * 3.09$ & 0.0020 \\
\hline DYLD $_{\text {it-4 }}$ & 1.4410 & 1.39 & 0.1640 \\
\hline \multicolumn{4}{|c|}{ Panel B: Composite Equal-Weighted Equity REIT Returns as Market Proxy $\left(\mathbf{R}^{2}=0.39\right)$} \\
\hline Variable & Coefficient & t-statistic & probability $<\mathrm{t}$ \\
\hline intercept & -0.2218 & $* * * 7.52$ & $<0.0001$ \\
\hline $\mathrm{R}_{\mathrm{it}-1}-\mathrm{R}_{\mathrm{mt}-1}$ & 0.0765 & 0.34 & 0.7326 \\
\hline $\mathrm{R}_{\mathrm{it}-2}-\mathrm{R}_{\mathrm{mt}-2}$ & 0.0005 & 0.00 & 0.9987 \\
\hline $\mathrm{R}_{\mathrm{it}-3}-\mathrm{R}_{\mathrm{mt}-3}$ & 0.0956 & 0.32 & 0.7508 \\
\hline $\mathrm{R}_{\mathrm{it}-4}-\mathrm{R}_{\mathrm{mt}-4}$ & 0.1670 & 0.76 & 0.4443 \\
\hline DYLD $_{\mathrm{it}-1}$ & 2.0810 & $* * 1.99$ & 0.0463 \\
\hline DYLD $_{\text {it-2 }}$ & 1.2460 & 1.15 & 0.2491 \\
\hline DYLD $_{\text {it-3 }}$ & 3.3700 & $* * * 3.08$ & 0.0020 \\
\hline DYLD $_{\text {it }-4}$ & 1.4180 & 1.37 & 0.1705 \\
\hline
\end{tabular}




\begin{tabular}{|c|c|c|c|}
\hline \multicolumn{4}{|c|}{ Panel C: NYSE/AMEX/Nasdaq Value-Weighted Portfolio Return as Market Proxy $\left(\mathbf{R}^{2}=0.38\right)$} \\
\hline Variable & Coefficient & t-statistic & probability $<\mathrm{t}$ \\
\hline intercept & -0.2314 & $* * *-7.89$ & $<0.0001$ \\
\hline $\mathrm{R}_{\mathrm{it}-1}-\mathrm{R}_{\mathrm{mt}-1}$ & 0.1330 & 0.39 & 0.6979 \\
\hline $\mathrm{R}_{\mathrm{it}-2}-\mathrm{R}_{\mathrm{mt}-2}$ & 0.2510 & 0.56 & 0.5724 \\
\hline $\mathrm{R}_{\mathrm{it}-3}-\mathrm{R}_{\mathrm{mt}-3}$ & 0.0132 & 0.03 & 0.9762 \\
\hline $\mathrm{R}_{\mathrm{it}-4}-\mathrm{R}_{\mathrm{mt}-4}$ & 0.1080 & 0.34 & 0.7374 \\
\hline DYLD $_{\mathrm{it}-1}$ & 2.2900 & $* * 2.20$ & 0.0281 \\
\hline $\mathrm{DYLD}_{\mathrm{it}-2}$ & 1.1340 & 1.05 & 0.2938 \\
\hline DYLD $_{\text {it-3 }}$ & 3.3110 & $* * * 3.03$ & 0.0025 \\
\hline DYLD $_{\text {it-4 }}$ & 1.4360 & 1.39 & 0.1652 \\
\hline \multicolumn{4}{|c|}{ Panel D: Composite Value-Weighted Equity REIT Returns as Market Proxy $\left(\mathbf{R}^{2}=0.38\right)$} \\
\hline Variable & Coefficient & t-statistic & probability $<\mathrm{t}$ \\
\hline intercept & -0.2286 & $* * * 7.79$ & $<0.0001$ \\
\hline $\mathrm{R}_{\mathrm{it}-1}-\mathrm{R}_{\mathrm{mt}-1}$ & 0.1170 & 0.58 & 0.5639 \\
\hline $\mathrm{R}_{\mathrm{it}-2}-\mathrm{R}_{\mathrm{mt}-2}$ & 0.0820 & 0.30 & 0.7647 \\
\hline$R_{\mathrm{it}-3}-\mathrm{R}_{\mathrm{mt}-3}$ & 0.0014 & 0.01 & 0.9957 \\
\hline$R_{\mathrm{it}-4}-R_{\mathrm{mt}-4}$ & 0.1740 & 0.88 & 0.3768 \\
\hline DYLD $_{\text {it-1 }}$ & 2.1550 & $* * 2.06$ & 0.0390 \\
\hline DYLD $_{\text {it-2 }}$ & 1.1202 & 1.11 & 0.2658 \\
\hline DYLD $_{\text {it-3 }}$ & 3.3590 & $* * * 3.07$ & 0.0021 \\
\hline DYLD $_{\text {it-4 }}$ & 1.4220 & 1.37 & 0.1693 \\
\hline
\end{tabular}

* Significance at $10 \%$ level

** Significance at $5 \%$ level

*** Significance at $1 \%$ level

\section{Sub-period Effects}

My sample period covers distinct and different economic periods. Years 1995 to 1997 marked a big REIT IPO period. The year 1998 through the end of March 2000 was the tech bubble period and real estate as an investment opportunity suffered. Why invest in a relatively non-liquid asset when you can get $50 \%$ returns elsewhere? April 2000 to end of September 2001 covers the period of the tech bubble crash. The recovery period covers the rest of the sample. I use Table 4 to test for the most influential sub-period, displaying the bubble and post-bubble period.

\section{Table 4}

Prior REIT Performance and Change in Mutual Fund Holdings (Economic Sub-Periods)

The change in quarterly mutual fund holdings is the result of the following relationship:

$$
\Delta H l d_{\mathrm{it}}=\alpha_{0 \mathrm{i}}+\sum_{\mathrm{k}=1}^{4} \beta_{\mathrm{i}}\left(\mathrm{R}_{\mathrm{i} \cdot \mathrm{k}}-\mathrm{R}_{\mathrm{m}-\mathrm{k}}\right)+\sum_{\mathrm{k}=1}^{4} \beta_{\mathrm{i}}\left(\mathrm{DYLD}_{\mathrm{i} t \mathrm{k}}\right)+\varepsilon_{\mathrm{it}} ;
$$

where $\mathrm{R}_{\mathrm{it}-\mathrm{k}}=$ return of stock $i$ for quarter $t-k(k=1$ to 4$), \mathrm{R}_{\mathrm{mt}-\mathrm{k}}=$ return on a market index portfolio for quarter $t-k,(\mathrm{k}=1$ to 4$)$, $\mathrm{DYLD}_{\mathrm{it}-\mathrm{k}}=$ dividend yield for quarter $t-k(k=1$ to 4$)$, and $\Delta H l d_{\mathrm{it}}=$ change in percentage holdings of stock $i$ from quarter $t-1$ to quarter $t$. The CRSP NYSE/AMEX/Nasdaq equal-weighted portfolio quarterly returns serve as the market proxy. Panel A looks at the tech bubble period. Panel B covers the bubble crash period.

\begin{tabular}{|l|c|c|c|}
\hline \multicolumn{1}{|c|}{ Panel A: Tech Bubble (1/1/1998-3/31/2000) $\left(\mathbf{R}^{2}=\mathbf{0 . 3 6}\right)$} & t-statistic & probability $<~$ \\
\hline \multicolumn{1}{|c|}{ Variable } & -0.2161 & $* * *-4.61$ & $<0.0001$ \\
\hline intercept & 0.1020 & 0.34 & 0.7305 \\
\hline $\mathrm{R}_{\mathrm{it}-1}-\mathrm{R}_{\mathrm{mt}-1}$ & 0.2210 & 0.57 & 0.5685 \\
\hline $\mathrm{R}_{\mathrm{it}-2}-\mathrm{R}_{\mathrm{mt}-2}$ & 0.7710 & $* * 2.04$ & 0.0410 \\
\hline $\mathrm{R}_{\mathrm{it}-3}-\mathrm{R}_{\mathrm{mt}-3}$ & 0.2000 & 0.71 & 0.4800 \\
\hline $\mathrm{R}_{\mathrm{it}-4}-\mathrm{R}_{\mathrm{mt}-4}$ & 2.1550 & 1.34 & 0.1819 \\
\hline $\mathrm{DYLD}_{\mathrm{it}-1}$ & 2.2530 & 1.47 & 0.1417 \\
\hline DYLD $_{\mathrm{it}-2}$ & 1.5600 & 1.00 & 0.3152 \\
\hline DYLD $_{\mathrm{it}-3}$ & 2.0150 & 1.31 & 0.1911 \\
\hline DYLD $_{\mathrm{it}-4}$ & & & \\
\hline
\end{tabular}




\begin{tabular}{|l|c|c|c|}
\hline \multicolumn{1}{|c|}{ Pariable } & Coefficient & t-statistic & probability $<\mathbf{t}$ \\
\hline intercept & -0.3253 & $* * *-5.05$ & $<0.0001$ \\
\hline $\mathrm{R}_{\mathrm{it}-1}-\mathrm{R}_{\mathrm{mt}-1}$ & 0.5570 & 1.35 & 0.1782 \\
\hline $\mathrm{R}_{\mathrm{it}-2}-\mathrm{R}_{\mathrm{mt}-2}$ & 0.4250 & 0.75 & 0.4513 \\
\hline $\mathrm{R}_{\mathrm{it}-3}-\mathrm{R}_{\mathrm{mt}-3}$ & 0.2730 & 0.46 & 0.6466 \\
\hline $\mathrm{R}_{\mathrm{it}-4}-\mathrm{R}_{\mathrm{mt}-4}$ & 1.0710 & $* * 2.39$ & 0.0168 \\
\hline $\mathrm{DYLD}_{\mathrm{it}-1}$ & 1.7790 & 0.88 & 0.3795 \\
\hline $\mathrm{DYLD}_{\mathrm{it}-2}$ & 7.3940 & $* * * 3.38$ & 0.0007 \\
\hline DYLD & & \\
\hline DYLD $_{\mathrm{it}-4}$ & 7.6350 & $* * * 3.59$ & 0.0003 \\
\hline
\end{tabular}

* Significance at $10 \%$ level

**Significance at $5 \%$ level

*** Significance at $1 \%$ level

Panel A shows the results during the tech bubble period (sample dates 1/1/1998 to 3/31/2000). I find no evidence of lagged market-adjusted returns affecting changes in holdings, keeping lagged dividend yield constant. The expected positive sign is evident. There is a significant negative intercept that suggests a decrease in the average holding of a REIT by a mutual fund of $0.2161 \%$ if all independent variables were zero. This result is significant at the $1 \%$ level; the $\mathrm{R}^{2}$ value is 0.36 . There is no significant relationship between lagged dividend yield and change in percentage holdings. Panel B shows the results during the bubble crash period (sample dates 4/1/2000 to $9 / 30 / 2002$ ). There is significant evidence of four quarter lagged market-adjusted returns affecting changes in holdings, keeping lagged dividend yield constant. The expected positive sign is evident. A change of one percent in market adjusted four quarter lagged return produces a 1.07\% change in percent holdings. There is a significant negative intercept that suggests a decrease in the average holding of a REIT by a mutual fund of $0.3253 \%$ if all independent variables were zero. This result is significant at the $1 \%$ level. There is a significant relationship between lagged dividend yield and change in percentage holdings. Lagged two and three quarter dividend yield produces a $7.35 \%$ and $7.64 \%$ change in percent holding respectively; the $\mathrm{R}^{2}$ value is 0.38 . These results suggest there was increased investment in real estate related assets during this period and investors held on to these assets. An increase in dividend payout also contributed to investment.

Overall the tech bubble crash period had the most profound effect on changes in holdings. Real estate related assets became attractive again when the exuberance of the bubble period disappeared and cooler heads prevailed.

\section{Effects of Ex-Post Performance Measures on Change in Percentage Holdings}

\section{Performance Based on Funds From Operations (FFO)}

I test for effects of funds from operations performance based abnormal returns based on changes in percentage holdings. Funds from operations performance (FFOP) are the percentage change of FFO for a given security over the prior quarter. I use Table 5 to show the results. There is significant evidence of four quarter lagged market-adjusted returns affecting changes in holdings, keeping lagged dividend yield constant. The expected positive sign is evident. There is a significant negative intercept that suggests a decrease in the average holding of a REIT by a mutual fund of $0.1933 \%$ if all independent variables were zero. This result is significant at the $1 \%$ level. There is a significant relationship between lagged dividend yield and change in percentage holdings. Lagged one and three quarter dividend yield produces a $4.52 \%$ and $2.87 \%$ change in percent holding respectively; the $\mathrm{R}^{2}$ value is 0.36. The table only shows the results using the Composite REIT equal-weighted returns as a market proxy; the results using the other market proxies are similar. 
Table 5

Prior REIT Performance and Change in

Mutual Fund Holdings (FFO)

The change in quarterly mutual fund holdings is the result of the following relationship:

$\Delta H d_{\mathrm{it}}=\alpha_{0 \mathrm{i}}+\sum_{\mathrm{k}=1}^{4} \beta_{\mathrm{i}}\left(\mathrm{FFOP}_{\mathrm{i}-\mathrm{k}}-\mathrm{FFOP}_{\mathrm{m}-\mathrm{k}}\right)+\sum_{\mathrm{k}=1}^{4} \beta_{\mathrm{i}}\left(\mathrm{DYLD}_{\mathrm{i}-\mathrm{k}}\right)+\varepsilon_{\mathrm{it}} ;$

where $\mathrm{FFOP}_{\mathrm{it}-\mathrm{k}}=$ percentage increase (decrease) in FFO per share of stock $i$ for quarter $t-1$ to $t-4$, FFOP $\mathrm{mt}_{-1}=$ percentage increase (decrease) on an equal-weighted portfolio of equity REITs for quarter $t-1$ to $t-4, \mathrm{DYLD}_{\mathrm{it}-\mathrm{k}}=$ dividend yield for quarter $t-k(k=1$ to 4 ), and $\Delta H l d_{\mathrm{it}}=$ change in percentage holdings of stock $i$ from quarter $t-1$ to quarter $t-4$. I analyze the effects of REITs initially entering and completely exiting the mutual fund portfolio. If $\left(H l d_{\mathrm{it}}-H l d_{\mathrm{it}-1}\right)=H l d_{\mathrm{it}}$, the REIT is in an entry position. If $\left(H l d_{\mathrm{it}}-\right.$ $\left.H l d_{\mathrm{it}-1}\right)=-H l d_{\mathrm{it}-1}$, the REIT is in an exit position. The Composite REIT equal-weighted portfolio quarterly returns serve as the market proxy. Panel A looks at the entire sample. Panel B looks at the sample without entry and exit REITs.

\begin{tabular}{|c|c|c|c|}
\hline \multicolumn{4}{|c|}{ Panel A: Composite REIT Equal-Weighted Portfolio Return as Index (All REITs) $\left(\mathbf{R}^{2}=0.36\right)$} \\
\hline Variable & Coefficient & t-statistic & probability $<\mathrm{t}$ \\
\hline intercept & -0.1933 & $* * *-4.37$ & $<0.0001$ \\
\hline $\mathrm{FFOP}_{\mathrm{it}-1}-\mathrm{FFOP}_{\mathrm{mt}-1}$ & 0.0311 & 1.39 & 0.1660 \\
\hline $\mathrm{FFOP}_{\mathrm{it}-2}-\mathrm{FFOP}_{\mathrm{mt}-2}$ & 0.0002 & 0.01 & 0.9999 \\
\hline $\mathrm{FFOP}_{\mathrm{it}-3}-\mathrm{FFOP}_{\mathrm{mt}-3}$ & 0.0035 & 0.14 & 0.8895 \\
\hline $\mathrm{FFOP}_{\mathrm{it}-4}-\mathrm{FFOP}_{\mathrm{mt}-4}$ & 0.0256 & 0.98 & 0.3290 \\
\hline DYLD $_{\text {it-1 }}$ & 4.5200 & $* * * 2.69$ & 0.0071 \\
\hline DYLD $_{\text {it-2 }}$ & 1.6710 & 1.00 & 0.3171 \\
\hline DYLD $_{\text {it-3 }}$ & 2.8730 & $* * 2.31$ & 0.0212 \\
\hline DYLD $_{\text {it-4 }}$ & 0.8540 & 0.54 & 0.5917 \\
\hline \multicolumn{4}{|c|}{ Panel B: Composite REIT Equal-Weighted Portfolio Return as Index (No Entry or Exit REITs) $\left(\mathbf{R}^{2}=0.37\right)$} \\
\hline Variable & Coefficient & t-statistic & probability $<\mathrm{t}$ \\
\hline intercept & -0.2877 & $* * *-4.73$ & $<0.0001$ \\
\hline $\mathrm{FFOP}_{\mathrm{it}-1}-\mathrm{FFOP}_{\mathrm{mt}-1}$ & 0.4400 & 1.59 & 0.1113 \\
\hline $\mathrm{FFOP}_{\mathrm{it}-2}-\mathrm{FFOP}_{\mathrm{mt}-2}$ & 0.1951 & 0.65 & 0.5418 \\
\hline $\mathrm{FFOP}_{\mathrm{it}-3}-\mathrm{FFOP}_{\mathrm{mt}-3}$ & 0.0659 & 0.21 & 0.8310 \\
\hline $\mathrm{FFOP}_{\mathrm{it}-4}-\mathrm{FFOP}_{\mathrm{mt}-4}$ & 0.0171 & 0.54 & 0.5879 \\
\hline DYLD $_{\text {it-1 }}$ & 5.4690 & $* * * 2.73$ & 0.0063 \\
\hline DYLD $_{\text {it-2 }}$ & 3.2140 & $* 1.66$ & 0.0962 \\
\hline DYLD $_{\text {it-3 }}$ & 3.7840 & $* * 1.93$ & 0.0542 \\
\hline DYLD $_{\text {it }-4}$ & 1.2820 & 0.67 & 0.5020 \\
\hline
\end{tabular}

* Significance at $10 \%$ level

$* *$ Significance at $5 \%$ level

*** Significance at $1 \%$ level

I test for the effects of entry and exit REITs on the FFO analysis. Panel B uses a sample without entry and exit REITs, using the Composite equal-weighted index as a market proxy. There is no evidence of lagged marketadjusted FFO performance affecting changes in holdings, keeping lagged dividend yield constant. The expected positive sign is evident. There is a significant negative intercept that suggests a decrease in the average holding of a REIT by a mutual fund of $0.2877 \%$ if all independent variables were zero. This result is significant at the $1 \%$ level. There is a significant relationship between lagged dividend yield and change in percentage holdings. Lagged one, two and three quarter dividend yield produces a $5.47 \%, 3.21 \%$ and $3.78 \%$ change in percent holding respectively; the $\mathrm{R}^{2}$ value is 0.37 . I conclude that the change in real estate mutual fund holdings is influenced by entry and exit REIT dividend yields.

\section{CONCLUSION}

I look at real estate mutual funds and how managers change holdings of REITs that are the underlying assets. I test for a relationship that one to four lagged market-adjusted returns and dividend yields have on the change in holdings. The entire sample shows a strong effect of lagged dividend yields on the change in holdings. When the quarterly composite equity REIT returns are used as a market proxy, the market-adjusted returns have a significant positive effect on the change in holdings. REITs that are initially added (entry) or completely removed (exit) by the fund manager can offer misleading results when he holding relationship is examined. When the 
aforementioned REITs are removed from the sample I find a stronger contribution of lagged dividend yields to the change in holdings.

There are four distinct economic periods in my sample that are studied. There is no significant relationship by lagged market-adjusted returns. Lagged dividend yields have a significant relationship with the change in holdings during the tech bubble period of $1 / 1 / 1998$ to 3/31/2000. The bubble crash period from 4/1/2000 to 9/30/2002 was a favorable one for real estate related assets, which is evidenced by the results.

I look at ex-post performance measures based on funds from operations (FFO) to determine if lagged market-adjusted returns and dividend yield affect the change in holdings. No significant results using FFO as a variable were found.

\section{AUTHOR INFORMATION}

Russell M. Price, Ph.D. joined the Howard University faculty in Fall 2006. He teaches courses in Macroeconomics, Financial Management, Finance Principles, Financial Modeling, Financial Markets/Institutions and Commercial Real Estate/Housing Finance. He also serves as a faculty advisor of the Howard University Real Estate Club. He holds a B.S. in Civil Engineering from Cornell University in Ithaca, NY and a Ph.D. in Finance from The Florida State University in Tallahassee, FL. His research interests include real estate finance, asset pricing, valuation, mutual funds, mortgage pricing and REITs. His research appears in the American Journal of Business Education, Journal of Real Estate Research, Journal of Business and Economic Research, Journal of the Academy of Economics and Finance and Journal of Real Estate Portfolio Management. Russell M. Price is an Assistant Professor of Finance at Howard University. Address: Howard University School of Business, Department of Finance, International Business and Insurance, Room 531, 2600 Sixth Street NW, Washington, DC 20059. Office Phone: (202) 806-1639. Office Fax: (202) 986-4409. E-mail: r_price@ howard.edu.

\section{REFERENCES}

1. Badrinath, S. G. and Sunil Wahal (2002), "Momentum Trading by Institutions," Journal of Finance, 57 (6), 2449-2478.

2. Chui, Andy C. W., Sheridan Titman, and K. C. John Wei (2003), "Intra-Industry Momentum: The Case of REITs," Journal of Financial Markets, 6 (3), 363-387.

3. Fernando, Chitru S., Srinivasan Krishnamurthy, and Paul A. Spindt (1999), "Is Share Price Related to Marketability? Evidence from Mutual Fund Share Splits," Financial Management, 28 (3), 54-67.

4. Gibson, Scott, Assem Safieddine, and Sheridan Titman (2000), "Tax-Motivated Trading and Price Pressure: An Analysis of Mutual Fund Holdings," Journal of Financial and Quantitative Analysis, 35 (3), 369-386.

5. Grinblatt, Mark and Sheridan Titman (1989), "Mutual Fund Performance: An Analysis of Quarterly Portfolio Holdings," Journal of Business, 62 (3), 393-416.

6. Grinblatt, Mark and Sheridan L. Titman (1993), "Performance Measurement without Benchmarks: An Examination of Mutual Fund Returns," Journal of Business, 66 (1), 47-68.

7. Grinstein, Yaniv and Roni Michaely (2005), "Institutional Holdings and Payout Policy," Journal of Finance, 60 (3), 1389-1426.

8. Hartzell, Jay C., Muhlhofer, Tobias and Titman, Sheridan (2007), "Alternative Benchmarks for Evaluating REIT Mutual Fund Performance", Real Estate Economics, 38 (1), 121-154.

9. Hung, Szu-Yin Kathy and Glascock, John L. (2008), "Momentum Profitability and Market Trend: Evidence from REITs", Journal of Real Estate Finance and Economics, 37 (1), 51-69.

10. Jegadeesh, Narasimhan and Sheridan Titman (1993), "Returns to Buying Winners and Selling Losers: Implications for Stock Market Efficiency", Journal of Finance, 48 (1), 65-91.

11. Johnson, T. C. (2002), "Rational Momentum Effects", Journal of Finance, 57 (6), 585-608.

12. Rozeff, Michael S. (1998), "Stock Splits: Evidence from Mutual Funds," Journal of Finance, 53 (3), 335 349.

13. Vincent, Linda (1999), "The Information Content of Funds from Operations (FFO) for Real Estate Investment Trusts (REITs)," Journal of Accounting and Economics, 26 (1-3), 69-104. 